\title{
A CARNAVALIZAÇÃO DO DIABO NA LITERATURA BRASILEIRA: UM ESTUDO COMPARADO ENTRE ÁLVARES DE AZEVEDO E MACHADO DE ASSIS
}

\section{THE CARNIVALIZATION OF DEVIL IN BRAZILIAN LITERATURE: A COMPARATIVE STUDY BETWEEN ÁLVARES DE AZEVEDO AND MACHADO DE ASSIS}

\author{
Augusto Rodrigues da Silva-Junior ${ }^{1}$ \\ Marcos Eustáquio de Paula Neto ${ }^{2}$
}

DOI: 10.26512 /aguaviva.v3i1.12204

Recebido em: 18 abr. 2018

Aceito em: 23 mai. 2018

RESUMO: Pretende-se alcançar um entendimento sobre a perspectiva atribuída ao Diabo, na cultura popular do ocidente, e suas repercussões nas obras Macário (1852) de Álvares de Azevedo e A igreja do Diabo (1884) de Machado de Assis. Para o entendimento dessa personagem infernal, visto pela ótica da carnavalização (BAKHTIN, 2008) e da tanatografia, esse estudo trará sua memória bíblica, sua relativização no século XIX e sua presença em manifestações literárias ligadas à tradição da sátira menipeia.

Palavras-chave: Machado de Assis; Álvares de Azevedo; Carnavalização; Diabo.

\begin{abstract}
In this essay it is intended to reach and understanding about the outlook attributed to the devil, in the popular culture of the western civilization, and its repercussions in the literary works of Macario (1852) by Álvares de Azevedo and in A Igreja do Diabo by Machado de Assis (1884). In order to undersand this hellish character, analyzed from the point of view of carnivalization (BAKHTIN, 2008) and by the tanatography, this essay will cover its biblical memory, its relativization in the 19th century and its presence in literary manifestations connected to the tradition of menipea satire.
\end{abstract}

Keywords: Machado de Assis; Álvares de Azevedo; Carnavalization; Devil.

\footnotetext{
${ }^{1}$ Doutor em Literatura e Professor Adjunto IV em Literatura Brasileira na Universidade de Brasília (UnB). E-mail: augustorodriguesdr@ gmail.com

${ }^{2}$ Graduando em Letras pela Universidade de Brasília (UnB). E-mail: marcoseustaquio94@ hotmail.com
} 

nunca os aborreci tão cá de dentro, como aos demais que a minha essência negam.

(Fausto, GOETHE)

$\mathrm{Na}$ história da literatura brasileira o Diabo percorre linhas elucidativas da condição humana a partir de uma cultura e língua geral. Buscamos, neste momento, em perspectiva crítico-polifônica um entendimento a respeito da presença diabólica em Álvares de Azevedo e Machado de Assis. Por se tratar de um personagem constante em nosso imaginário, elegemos como contraponto para nossa abordagem a presença do chifrudo na tradição cristã, por meio do texto bíblico, e seu eco na tradição popular. Para tal, elegemos como pressupostos teóricos os conceitos de carnavalização e de dialogismo (BAKHTIN, 1997) em pontos de contato com a tanatografia (SILVA-JUNIOR, 2014). Conjugando a ideia de uma escrita de morte, esta epistemologia comparativista interessase por manifestações literárias e populares que buscam o desassossego - e nada é mais desassossegante que a imagem e a presença do dito-cujo.

As obras literárias selecionadas para esse estudo foram: a peça teatral Macário (1852) e o conto A Igreja do Diabo (1884). Embora nossa análise não seja voltada para a crítica genética é fato que a interrupção precoce do texto de Azevedo, em contraponto ao conto bem articulado de Machado, deve ser considerada. Enquanto o autor da Lira dos Vinte anos (1853) não conseguira ver nenhuma de suas obras publicadas em vida, o escritor fluminense teve uma carreira produtiva e consolidada. Desse modo, as obras por nós selecionadas tiveram suas produções realizadas em circunstâncias bastante distintas, o que certamente influencia na representação do Diabo nos dois textos. Para ampliarmos nosso entendimento das obras e dos temas abordados nelas, necessário se torna retomarmos também um estudo de outra esfera.

Em exercício de comparação historiográfica os estudos de Laura de Mello e Souza são cabais para pensarmos questões de demonologia no período de colonização entre os séculos XVI e XVII no Brasil. A presença do coisa ruim na Terra de Santa Cruz surge num movimento de forças colonizatórias: "no cruzamento de concepções e discursos vários (...) o carnaval ensurdecedor se desenrolaria” (SOUZA, 1995, p. 378). Ao contrário da prosaística do século XIX que vai permitir a ascensão do indivíduo e do humano, nesse longo período o tinhoso é figura e instrumento de dominação. O melhor exemplo desse período de catolicismo carnavalizado é a presença do Diabo no teatro de José de Anchieta 
em que o "embate entre o Bem e o Mal como fundador da própria identidade brasileira" surge com muita força (SOUZA, 1993, p. 32).

Estabelecida esse grifo primeiro com relação à presença demoníaca na cultura e literatura brasileira, introduzimos nossa leitura de Álvares de Azevedo que, embora cheia de "defeitos e limitações que a deformam" (CANDIDO, 2012, p. 493), conforme grifado por Candido, possui uma "magia que dela emana" (ibid, p. 493). Devido a tais condições é dito pelo crítico, em ensaio intitulado de "A educação pela noite", a segunda parte do Macário aparece desprovida da coerência da primeira. Supõe-se disso que o poeta não havia concluído sua obra.

Nossa análise, portanto, recairá na primeira parte da peça em que a visão diabólica elucida-se por completo. A insistência no verbo é orgânica, mantém a mesma raiz de Lúcifer (latim Elucidare). Nessa primeira parte, intitulada de "Primeiro episódio", o tinhoso não se apresenta abruptamente. Sua identidade é revelada apenas depois, em sonho. Tal substância onírica torna incerta a veracidade dos episódios desencadeados na história e, graças a essa ambiência fantasiosa. Numa ambiência repleta de incertezas, Macário passa a compreender a visão satânica: "És o diabo em pessoa. Para ti nada há bom. Pelo que vejo, na criação só há uma perfeição, a tua. Tudo o mais nada vale para ti. Substância da soberba, ris de tudo o mais embuçado no teu desdém" (AZEVEDO, 2010, p. 43). Nessa passagem, de herança goetheana, Macário queixa-se do ofício do demoníaco: contestar tudo e a todos.

Para compreendermos melhor essa figura em sua totalidade, e sua representação na cultura e na literatura do ocidente, partimos de um estudo de Eudoro de Sousa sobre o tema, que tece a seguinte ligação: "Diabólico' tem por étimo o verbo grego diabàllein, que, entre outros, tem o significado de 'separar', de modo que "diabólico" quereria dizer "qualidade inerente ao separado" (SOUSA, p. 49, 1995). Com isso, há de se formular uma primeira teoria a respeito do ser infernal: ele detém a característica intrínseca de negar e romper com as normas vigentes do mundo e da sociedade - nisso reside, também, a tanatografia. A negação, por um processo de desassossego insolúvel, levando à contradição.

Bakhtin (2008) parte da distinção entre tradição cristã e cultura popular, quando determinadas por meio da fronteira do que seria oficial e não-oficial, para mostrar como classes dominantes da sociedade tentaram impor suas convenções aos mais desfavorecidos. O confronto muitas vezes providenciado pelas classes populares, 
excepcionalmente quando ia de encontro à Igreja católica, era construído no interior da própria religião. Assim, elegia-se uma coletividade de figuras endiabradas para compor a multiplicidade de vozes populares. Aproveitando-se da figura animalesca do chifrudo única no imaginário cristão - escritores inventaram suas próprias criaturas catabáticas e anabáticas para refutar e contrapor esses preceitos oficiais e promover tal junção. Enquanto no texto bíblico o vemos retratado como "aquele que não permanecera na verdade" (JO 8:44), nas obras selecionadas por nós vemos um personagem brincalhão que, totalmente hostil à verdade única arraigada em nossas mentes, nega o sério e amplia as possibilidades de se pensar o mundo.

A perspectiva do tinhoso aproxima-se da carnavalização como ato de romper com padrões e preceitos oficiais. Bakhtin, em seu estudo de maior fôlego sobre cultura popular, realiza semelhante aproximação:

Mas o diabo do mistério não é apenas uma figura extra-oficial, ele é também uma personagem ambivalente e assemelha-se, nesse aspecto, ao tolo e ao bufão. Ele representa a força do "baixo" material e corporal que dá a morte e regenera. Nas diabruras, as personagens dos diabos tinham aspectos carnavalescos. Vemos por exemplo que Rabelais armou os diabos de Villon com utensílios de cozinha (BAKHTIN, 2008, p. 232).

O aspecto carnavalesco na obra de François Rabelais - pontuado por Erich Auerbach ao citar as "farsas grosseiras, a visão criatural do corpo humano, a falta de vergonha e de descrição no campo sexual, a mistura de um tal realismo com conteúdos satíricos etc.” (AUERBACH, 1971, p. 236) percorre os mais diferentes diabos da tradição - Dante, Anchieta, Goethe, Guimarães Rosa e Saramago. O dialogismo que une essas várias obras tem como pilar a tradição menipéica, caracterizada pela sátira, diálogos dos mortos, manifestações do gênero cômico-sério e a carnavalização estilizada:

Segundo Bakhtin, a carnavalização é o processo através do qual o discurso popular intrinsecamente ambíguo e irreverente singularmente expresso nos ritos e festivais carnavalescos da Antiguidade, da Idade Média e do Renascimento, até o século dezessete - irromperia no âmbito dos discursos formalizados e transformados em 'gêneros' pela literatura oficial de uma dada sociedade, subvertendo-os e revolucionarizando-os (SÁ REGO, 1989, p. 22).

A figura endiabrada em Macário realiza isso ao apresentar um novo mundo ao protagonista por meio do sonho, clima reverso daquele visto sob a luz do dia. Já no conto 
machadiano A igreja do Diabo, Satã é preconcebido como um ser desprezível e miserável. O diabo literário do XIX é muito mais próximo do humano, como se as questões contraditórias fossem as próprias questões mais urgentes.

Machado revoluciona esta representação, pois o ser divertido, cínico e cético e o próprio Deus são submetidos a novas interpretações pelo ser humano, dotado de um contínuo desassossego de pensamento. Nesse contraponto, o Diabo surge como um vaidoso por desejar fundar uma nova religião no mundo. Mas, machadianamente, seu desejo é demasiado humano e o desespero é latente diante da própria condição existencial. Deus lança seu riso voltairiano e a teoria das eternas contradições humanas é composta.

Para construir dialogicamente esta aura diabólica é necessário trazer a Hora do Diabo (1997), do poeta português Fernando Pessoa. Texto escrito na primeira década do século XX e sumamente importante para pensar uma tradição de faustos, mefistos e pactos. Entre os aspectos dessa narrativa a aura noturna de Azevedo e a aura soturna de Machado povoam o ambiente pessoano. Nesta tríade melancólico-galhofeira temos uma galeria de demônios a sentir o mal-estar da humanidade em língua portuguesa.

Em breve conversa com uma senhora, interrogado por ela a respeito da sua condição de sustentar as coisas, negando-as, o Diabo pessoano responde:

É a lei da vida, minha senhora. O corpo vive porque se desintegra, sem se desintegrar demais. Se não se desintegrasse segundo a segundo, seria um mineral. A alma vive porque é perpetuamente tentada, ainda que resista. Tudo vive porque se opõe a qualquer coisa. Eu sou aquilo a que tudo se opõe. Mas, se eu não existisse, nada existiria, porque não havia a que opor-se, como a pomba do meu discípulo Kant que, voando bem no ar leve, julga que poderia voar melhor no vácuo (PESSOA, p. 06, 2015).

Como podemos observar, esse personagem se caracteriza por ser aquele que move contradições. Essa tensão na contradição é inerente ao seu ser e à existência de tudo que é diabólico. Apropriando-se de um exemplo filosófico para fundamentar sua explicação, o cornudo pessoano se compara parodicamente (à pomba de) Kant, que julga poder voar melhor no vácuo, esquecendo-se de que a tensão é o que a mantém no ar. Isso justifica a condição de recusa inerente a tudo que vive, pois seriam as tensões da vida as únicas responsáveis por sua continuidade, assim como mostra nossa referência à pomba.

Nos dizeres de Eudoro de Sousa, essa condição de tensão também é intrínseca à condição humana, pois o homem é igualmente um ser de recusa: 
"Diabólicos" não podemos deixar de ser, na maior parte do trajeto da nossa vida. A palavra qualifica um poderoso ingrediente do quer que passe por "Humanitas". Quanto mais predomine em nós, intelecto e vontade - que é sempre vontade de querer uma coisa só, e recusar tudo o que ela não é -, mais 'diabólicos' seremos, mais separadores. (SOUSA, 1995, p. 48).

Quando se verifica esse elemento satânico na essência do ser, referida nas palavras de Sousa como Humanitas, constatamos que a obra literária fora impregnada na mesma ótica infernal. Esse elemento separador se torna, portanto, imprescindível para a compreensão do "desassossego". A substância onírica desses diálogos, então, faz com que o sentido da escrita passe por um processo tanatográfico que leva à decomposição biográfica (SILVA-JUNIOR, 2008). Apenas nesses silêncios de dúvida e de tensão que o diabo e reinaugura-se em visões artísticas. O sonho, neste caso, se torna um cenário perfeito para a realização da visão diabólica. Sobre isso o príncipe das trevas também expõe suas perspectivas: "O bom sonhador não acorda. / Eu nunca acordei. / Deus mesmo (Já uma vez ele mo disse) / duvida que não durma" (PESSOA, 2015, p. 06). Além de esclarecer o conteúdo de si próprio, o capeta fala para a senhora até mesmo sobre Deus. A reversibilidade é uma marca inerente do personagem. Além de surgir em sonho, tornando-o incerto aos olhos dos infelizes que se deparam com ele, o Demônio nos surpreende com suas afirmações sobre Deus, o ser preconcebido como absoluto e soberano.

Para um olhar dialógico e comparativista é necessário evocar outras obras do Bruxo do Cosme Velho que abordam a figura satânica. Diante da vastidão de referências que podemos trazer sobre essa temática na produção machadiana - A Ópera de Dom Casmurro (1899), a metáfora do xadrez genesíaco em Esaú e Jacó (1904), o conto $O$ Sermão do Diabo (1893), o conto Adão e Eva (1997) etc.... -, para compreendermos os “diálogos diabólicos" das obras antepostas para análise, invocamos as Memórias Póstumas de Brás Cubas (1881):

A lembrança de Virgília aparecia de quando em quando, à porta, e com ela um diabo negro, que me metia à cara um espelho, no qual eu via ao longe Virgília desfeita em lágrimas; mas outro Diabo vinha, cor-derosa, com outro espelho, em que se refletia a figura de Nhã-loló, terna, luminosa, angélica (MACHADO, 2010, p. 260). 
Há de se reconhecer o papel predominante da presença do tinhoso ao trazer mundividências que confrontam as percepções comuns que temos do mundo e da vida. $\mathrm{O}$ caso das Memórias Póstumas exemplifica isso de forma bastante curiosa. Os dois espelhos, os dois chifrudos e as duas mulheres são representações da dicotomia provocadora do drama da indecidibilidade vivido pela imensa galeria tanatográfica de personagens machadianos.

O espelho, símbolo caro à obra de Machado, surge enquanto instrumento que possibilita a ótica satânica, pois é nele que muitas vezes o mundo surge representado em sua total reversibilidade. Os dois Diabos, da cena mencionada, trazem, cada um, um espelho. Esse fato legitima nossa tese de que há uma pedagogia satânica que inclui a reversibilidade, a contradição, a indecidibilidade e o desassossego. Seus princípios engendram a multiplanaridade. Lembremos uma genealogia literária de personagens que foram acompanhadas pelo coisa-ruim, a exemplo dos nossos personagens Macário e Fausto e tantas variantes, tais como Dorian Gray e Riobaldo.

Vale ainda pensar na presença pactária e truncada de Dante nos livros assinados pelo Conselheiro Aires. A epígrafe de Esaú e Jacó "Dico, che quando l'anima mal nata" (MACHADO, 1992, p. 947) que retorna citada no capítulo XII (p. 966) articula um conjunto emblemático de elementos contraditórios. Aproximando o diário de Aires da Igreja do Diabo, numa perspectiva da tanatografia, temos:

Ao Conselheiro, quando vivo, coube a análise das contradições humanas - teoria já presente na década de 80 se recordarmos A igreja do Diabo - conto da entressafra romanesca. Depois, defunto, ressurge em complementos publicáveis do diário, tecendo as suas cartomancias e diplomacias enxadristas (SILVA-JUNIOR, 2014, p. 6-7).

O jogo machadiano dos mistérios e revelações na ordem do humano recupera toda a galeria diabólica erigida por Dante. Como coloca Borges (2011), em um dos seus Ensaios Dantescos, a Divina Comédia é uma grande estampa que indaga sobre "os movimentos, as sondagens, as aventuras, os vislumbres e as premonições do espírito humano" (BORGES, 2011, p. 44).

A fórmula de Azevedo, não menos calcada na tanatografia como uma arqueologia da sabedoria, é fulcral para este processo. A carnavalização e a catábase de memória dantesca é realizada, no mínimo, por meio de dois processos distintos. No primeiro caso, ela se dá a partir do diálogo entre Macário e o tinhoso, que o apresenta a uma nova forma 
de ver o mundo. No instante em que Macário, apertando as mãos de Satã, estabelece implicitamente um pacto e adota a visão diabólica a contradição humana é firmada numa eternidade cotidiana e numa mundana do eterno. Esse ritual inicial estabelecido entre Macário e o até então desconhecido, aconteceu antes do homem ser introduzido em seus sonhos:

\author{
O desconhecido \\ Aperta a minha mão. Até sempre: na vida e na morte! \\ Macário \\ Até sempre, na vida e na morte! \\ O desconhecido \\ E o teu nome? \\ Macário \\ Macário.
}

Se não fosse enjeitado, dir-te-ia o nome do meu pai e o de minha mãe. Era decerto alguma libertina. Meu pai, pelo que penso, era padre ou fidalgo.

O desconhecido

Eu sou o Diabo. Boa noite, Macário.

(AZEVEDO, 2010, p. 37)

O aperto de mãos descrito sugere o pacto de Macário com o tinhoso. Esse é o passo inicial para o desencadeamento onírico da história. Apenas após adormecer Macário se torna consciente do fato de ser o próprio capeta a figura com quem fala. Nessa viagem onírica, então, a ótica infernal se manifestará a partir de processos de carnavalização.

No conto A Igreja do Diabo, por sua vez, movimento semelhante é estabelecido. Satanás, autointitulado de "o espírito que nega" (MACHADO, 2012, p. 364), decide fundar sua própria Igreja, que defende um verdadeiro projeto de negação, pois se caracteriza por ir contra todos os mandamentos de Deus. A carnavalização acontece a partir da proposta da imitação dos princípios cristãos. Fundar uma igreja, estabelecer-se no mundo, manter uma prática de culto à imagem e tantas variantes de adoração parece ser o ideal para o demônio. Mas, ao contrário do que espera, carnavalescamente, os vícios se tornam virtudes e as virtudes se tornam vícios. Na igreja do bem o homem fará o mal, já na igreja do tinhoso todos optarão por fazer o bem, pois, no fundo, céticos como Machado 
demonstram que a humanidade instaura-se para além de uma dicotomia maniqueísta. Não é o tabu o problema, mas o arbítrio em constante movimentação desassossegada.

Essa ambivalência, possibilitada pela radical alternância da proposta satânica, presente nos dois textos, foi elucidada por Candido (1989) ao pensar a respeito da conexão existente entre Macário e A noite na taverna. Para o crítico, essa atmosfera diabólica tem o poder de desenvolver o lado escuro do indivíduo:

Se estruturalmente o Macário e A noite na taverna estão ligados, no que toca os significados profundos haveria nesta ligação uma pedagogia satânica visando a desenvolver o lado escuro do homem, que tanto fascinou o Romantismo e tem por correlativo manifesto a noite, cuja presença envolve as duas obras e tantas outras de Álvares de Azevedo como ambiente e signo (CANDIDO, 1989, p. 18).

Esse ambiente, denunciado nas duas obras do poeta, também pode ser encontrado no conto machadiano. Assim como há uma pedagogia satânica que liga a obra de Macário ao diálogo que compõe A noite na Taverna, o plano diabólico no conto de Machado realiza projeto semelhante: desenvolver o lado contraditório do humano.

Essa pedagogia diabólica apontada por Candido se torna ainda mais elucidativa nos contos de Histórias sem data: "Há muitos modos de afirmar; há só um de negar tudo" (MACHADO, 2012, p. 362). Este caminho radical é o princípio que levará personagens e narradores a confrontarem qualquer projeto monológico no mundo. O projeto de negação de Deus, o anseio de Igreja, a inveja das pompas religiosas são sentimentos profundamente humanos que, na pena carnavalizada, sustenta interpretações singularíssimas que o endiabrado tem do mundo: "Nego tudo. A misantropia pode tomar aspecto de caridade; deixar a vida aos outros, para um misantropo, é realmente aborrecêlos..." (MACHADO, 2012, p. 364). A proposta do cornudo é uma nova perspectiva numa velha roupagem, que se realiza por meio de uma alternância cruel e radical. Ao retornar do céu, depois de uma conversa com Deus a respeito de seu plano, Satã inicia sua pregação e elucida suas perspectivas carnavalescas do mundo, da vida, e mesmo da arte:

Chamava ele que as virtudes aceitas deviam ser substituídas por outras, que eram as naturais e as legítimas. A soberba, a luxúria e a preguiça foram reabilitadas, e assim também a avareza, que declarou não ser mais do que a mãe da economia, com a diferença que a mãe era robusta, e a filha uma esgalgada. A ira tinha a melhor defesa na existência de Homero; sem o furor de Aquiles, não haveria a Ilíada: "Musa, canta a cólera de Aquiles, filho de Peleu..." O mesmo disse da gula, que 
produziu as melhores páginas de Rabelais, e muitos bons versos do Hissope; virtude tão superior, que ninguém se lembra das batalhas de Luculo, mas de suas ceias; foi a gula que realmente o fez imortal (MACHADO, 2012, p. 364-365).

Essa "suma diabólica" torna ainda mais lúcida essa nova perspectiva inaugurada no mundo. As aproximações articuladas, a franqueza de seu discurso e a invocação de nomes como Luculo e Rabelais são os maiores indícios da carnavalização de seus tratados. Essa galeria dialógica da tanatografia reforça-se parodiada na presença épica e nem tão heroica de Homero e Aquiles. Assim, a engenhosidade diabólica, atrelada ao arbítrio "libertado" pelo século XIX, tornou a igreja do Diabo um sucesso instantâneo entre os brasileiros da corte. A novidade de seu discurso, contudo, não se manteve. Com o tardar dos anos, as antigas virtudes passaram a ser praticadas pelos devotos às escondidas. Em desespero diante do curioso fenômeno, Satã retorna aos céus para inquirir Deus a respeito do motivo que teria levado os homens a praticarem as antigas virtudes, ao que Deus responde: “- Que queres tu, meu pobre Diabo? As capas de algodão têm agora franjas de seda, como as de veludo tiveram franjas de algodão. Que queres tu? é a eterna contradição humana" (MACHADO, 2012, p. 367).

No conto, até mesmo Satanás é vítima da eterna contradição humana. Essa característica, responsável pelos intermináveis desassossegos, teria feito do Diabo um refém, que, concentrado em seu ofício de negar tudo, se esquece da possibilidade de negar a si mesmo em ações de afirmação humana. Se em Álvares de Azevedo, ele parece ter maior consciência a respeito do que constitui o humano e, principalmente, a respeito do jovem Macário, em Machado é um Deus cético quem aparece como o profundo conhecedor da humanidade.

Importa notar que o reconhecimento da essência humana enquanto contradição pode ser exemplificado quando o Diabo de Azevedo comenta sobre a mulher que poderá ficar com Macário, desvelando os jogos criados por elas entre a aparência e a realidade: “Aquelas mulheres são repulsivas. O rosto é macio, os olhos lânguidos, o seio morno... Mas o corpo é imundo. Tem uma lepra que ocultam num sorriso" (AZEVEDO, 2010, p. 43). Cenas como essa, em que a encarnação do mal revela as podridões por trás dos rostos macios, trazem um Diabo que é, por si só, uma reversibilidade, pois nos traz uma outra visão de si mesmo. Essa alteração de perspectiva também se efetua para pensar a respeito da morte, conforme exposto na seguinte fala: "Se ali ficasses mais alguma hora, talvez ela te morresse nos braços. Aquela agonia, o beijo daquela moribunda talvez te 
regenerasse. Da morte nasce muitas vezes a vida" (AZEVEDO, 2010, p. 52). Ao tratar a morte como possibilidade para uma nova vida, mais uma vez o capiroto atinge sua paideia tanatográfica da alteridade, tornando o que antes era certeiramente o fim, a possibilidade para um novo começo. As falas de Satã na peça se aproximam-se dialogicamente do discurso satânico em Machado, vejamos o exemplo a seguir: "Macário - Esta cidade deveria ter o teu nome. Satã - tem o de um santo: é quase o mesmo" (AZEVEDO, 2010, p. 40). A aproximação criada entre o próprio capeta e um santo repete o movimento diabólico já lido no texto machadiano.

Para encaminhar o desfecho dessa discussão vale trazer ainda o conto $O$ Sermão do Diabo, de 1893, que traz um evangelho "segundo Machado de Assis". Há uma óbvia semelhança com o evangelho de Deus, contudo, ao mesmo tempo faz afirmações radicalmente opostas e desassossegadas. Assim como um espelho, responsável por representar reversamente tudo que mira, o conto traz um evangelho filosófico por confrontar "Escritura contra Escritura, breviário contra breviário" (MACHADO, 2012, p. 362). Nessa manifestação de uma carnavalização catolicizida e não exatamente do catolicismo carnavalizado o Diabo defende, entre vários ensinamentos, os seguintes:

\footnotetext{
“ $3^{\circ}$ Bem-aventurados aqueles que embaçam, porque eles não serão embaçados.

" $4^{\circ}$ Bem-aventurados os afoutos, porque eles possuirão a terra.

" $5^{\circ}$ Bem-aventurados os limpos das algibeiras, porque eles andarão mais leves.

" $6^{\mathrm{o}}$ Bem-aventurados os que nascem finos, porque eles morrerão grossos.

" $7^{\circ}$ Bem-aventurados sois, quando vos injuriarem e disserem todo o mal, por meu respeito. (MACHADO, 2012, p. 654)
}

O evangelho do tinhoso repete aquele mesmo efeito avistado na imagem do espelho no episódio citado das Memórias Póstumas: invocar a realidade em uma representação contrária àquela originária. Não por simples acaso o espelho serviu de instrumento para o Diabo mostrar ao amante de Virgília sua revelação. O evangelho do tinhoso repete o mesmo ato, pois imita o evangelho de Deus e altera radicalmente os ensinamentos para uma vida prática e cotidiana.

Defendemos, portanto, que há um movimento tanatográfico semelhante na construção dos dois personagens satânicos. O olhar de satã repetiu, nos dois autores, a fórmula ulteriormente desenhada por Bakhtin ao identificar a carnavalização em clássicos como o de François Rabelais. Esse movimento de alternância das virtudes pelos vícios, 
bem como das normas pelas exceções, é carnavalesco e diabólico, pois sempre promove uma "quebra", um rompimento com o hegemônico. Em um desses diálogos menipéicos e diabólicos, a seguinte interrogação é feita: “o que são vossas virtudes humanas senão a encarnação do orgulho?” (AZEVEDO, 2010, p. 44). Igualando as virtudes ao vício do orgulho, em uma indagação direcionada à Macário, Satã iguala sua perspectiva à visão da figura revolucionária do conto de Machado de Assis. Nos dois autores a visão demoníaca se caracteriza por um confronto às convenções e preceitos da sociedade. Conforme mostramos no decorrer das nossas análises, essas novas perspectivas enaltecem aquilo que é considerado humano, unem e confundem elementos que são originalmente concebidos como opostos e transforma derradeiras certezas em dispersas incertezas.

A “risada infernal” (AZEVEDO, 2010, p. 60) propõe a reversibilidade da vida e inaugura visões de alteridade nos dois autores. Essa capacidade permite a Belzebu colocar em evidência as contradições humanas. O absoluto dá lugar ao relativo. Essas traquinagens de "velho retórico" (MACHADO, 2012, p. 363), apresentadas por meio da tanatografia, induzem os indivíduos a pensarem além do que lhes é permitido pensar. $\mathrm{O}$ pacto não é com o invisível, afinal elucida tudo aquilo que é contraditório e humano.

\section{REFERÊNCIAS}

AUERBACH, Erich. Mimesis. São Paulo: Editora Perspectiva, 1971.

AZEVEDO, Álvares de. Macário. Porto Alegre: L\&PM, 2010.

BAKHTIN, Mikhail. A cultura popular na idade média e no renascimento: o contexto de François Rabelais. 6. ed. Brasília: Editora Universidade de Brasília, 2008.

BÍBLIA, João. Bíblia Sagrada. São Paulo: Geográfica, 2011. João 8: vers. 44.

BORGES, Jorge Luis. Nove ensaios dantescos \& a memória de Shakespeare. São Paulo: Companhia das Letras, 2011.

CANDIDO, Antonio. A educação pela noite e outros ensaios. São Paulo: Editora Ática, 1989.

Formação da Literatura Brasileira: Momentos Decisivos. Rio de Janeiro: Ouro sobre Azul, 2012.

PESSOA, Fernando. A Hora do Diabo. Lisboa: Assírio \& Alvim, 2004. 
Revista Água Viva

GOETHE, Johann Wolfgang Von. Fausto. Belo Horizonte: Editora Itatiaia, 1981.

MACHADO. Contos - Obra completa. Belo Horizonte: Itatiaia, 2012.

Memórias Póstumas de Brás Cubas. São Paulo:Abril, 2010.

Obra Completa. Rio de Janeiro: Editora Nova Aguilar, 1992.

SÁ REGO, Enylton. O Calundu e a Panacéia Machado de Assis, a sátira menipeia e a tradição luciânica. Rio de Janeiro: Forense universitária, 1989.

SILVA JR. Augusto Rodrigues. Morte e decomposição biográfica em Memórias Póstumas de Brás Cubas. 2008. 216f. Tese (Doutorado em Literatura Comparada) Instituto de Letras da UFF. Universidade Federal Fluminense, Niterói (RJ).

Tanatografia e morte literária: decomposições biográficas e reconstruções

dialógicas. ComCiência (online). N. 163. Campinas, nov. 2014, p. 1-8. Disponível em: $<$ http://comciencia.scielo.br/scielo.php?cript=sci_arttext\&pid=s1519-

76542014000900012\&lng=pt\&nrm=isso > Acesso em: 04 mar. 2018.

SOUSA, Eudoro de. Mitologia I Mistério e Surgimento do Mundo. $2^{\mathrm{a}}$ ed. Brasília: Ed. Universidade de Brasília, 1995.

SOUZA, Laura de Mello. Inferno atlântico - demonoligia e colonização nos séculos XVI-XVIII. São Paulo: Companhia das Letras, 1993.

. O diabo e a terra de Santa Cruz. São Paulo: Companhia das Letras, 1995. 